\title{
The Late Roman Insula in Nea Paphos in the Light of New Research
}

\author{
By Julia Mikocka*
}

\begin{abstract}
This paper deal with the House of Aion and the North-Eastern House which occupy part of a late Roman insula in Nea Paphos in Cyprus. The relative chronology of the buildings, the range, the spatial arrangement of both buildings, and the functions of the House of Aion are discussed. The research is based on the analysis of documentation and excavation reports on the work carried out in the House of Aion and the North-Eastern House between 1982 and 2008 and on the new observation of the arrangement of the walls, floors, mosaics, paintings, and the architectural decoration, as a result of fieldwork during 2014 - 2016. Research indicates that this was the longest existing insula in this part of the town. In this area, unusual features, not seen before in other buildings from the area of Nea Paphos, may be observed. My research fills in the gap in knowledge on Nea Paphos during the late Roman period. Studies of the House of Aion and the North-Eastern House will provide information concerning not only the architecture but also the social, administrative and economical changes that took place in Nea Paphos during the late Roman period. The study of these buildings will supplement our current knowledge of residential architecture and buildings performing public functions. To date, only limited number of information on insulas with residential and public buildings from Cyprus has been published.
\end{abstract}

\section{Introduction}

The aim of my research, which has been funded by the National Science Center (Cracow, Poland) ${ }^{1}$, is to study the architecture of buildings from the late Roman insula at Nea Paphos (see Figure 1). The fieldwork area is situated on the so-called Maloutena Plateau in the southwestern part of the ancient city on the Paphian Peninsula ${ }^{2}$, specifically the House of Aion and the North-Eastern House which are found in this location. In this paper the relative chronology of the buildings, the range, the functional and spatial arrangement of both buildings, and the role of the House of Aion will be explored. The results expand our knowledge on the fascinating and as yet unexplored insula from Nea Paphos and increase our knowledge of the history of this city in the late Roman period.

\footnotetext{
* PhD Candidate, University of Warsaw, Poland.

1. Prelude 10 (2015/19/ N/HS3/00907), grant from the National Science Center.

2. S. Medeksza, Willa Tezeusza w Nea Pafos. Rezydencja antyczna, (Wrocław, 1992), 82; J. Młynarczyk, Nea Paphos III. Nea Paphos in Hellenistic period (Varsovie 1990), 161.
} 


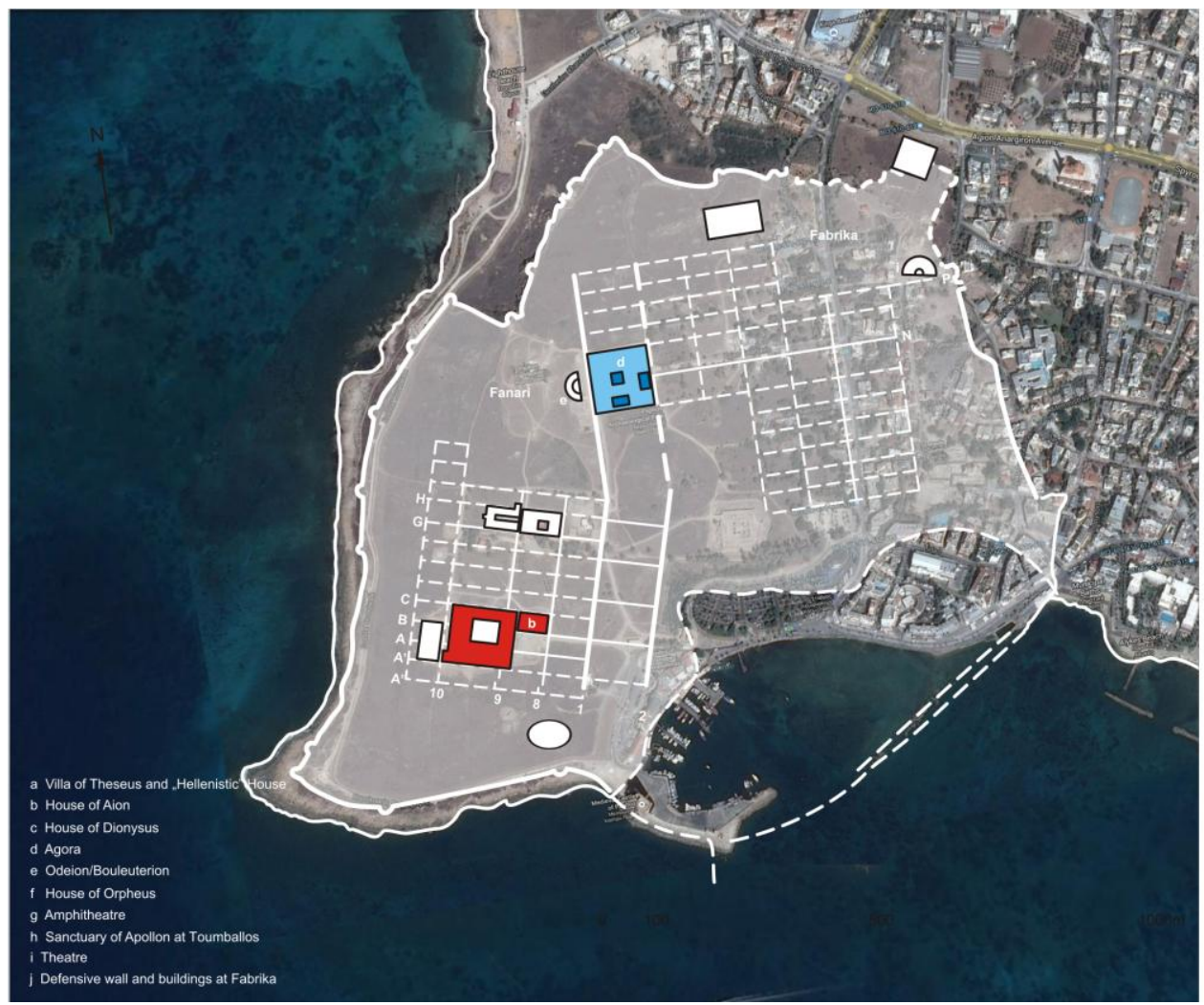

Figure 1. Plan of Nea Paphos during Hellenistic and Roman Times

Source: Based on S. Medeksza 1998, 37, fig.1; Google Earth (status as of Oct. 5th, 2014).

\section{Literature Review}

Excavations in the House of Aion and the North-Eastern House took place from the early 1980s until 2008. The excavations were at first conducted by the Research Station of Mediterranean Archaeology in Cairo, University of Warsaw, and since 1990 by the Polish Centre of Mediterranean Archaeology of the University of Warsaw. Until 2007, the head of the mission was Professor W. Daszewski, from 2008, Dr. H. Meyza. During many years of excavations, archaeologists have discovered and partly published mosaics ${ }^{3}$, pottery ${ }^{4}$, coins $^{5}$

3. M. T. Olszewski, "The iconographic programme of the Cyprus mosaic from the House of Aion reinterpreted as an anti-Christian polemic," in Et in Arcadia ego. Studia memoriae Professoris Thomae Mikocki dicata, ed. Vitoldo Dobrowolski (Varsoviae, 2013), 207 - 239; M. T. Olszewski, "L'allégorie, les mystères dionysiaques et la mosaïque de la Maison d'Aiôn de Nea Paphos à Chypre" ["The allegory, the Dionysian mysteries and the mosaic of the Aiôn House of Nea Paphos in Cyprus"], Bulletin de l'Association Internationale pour l'Étude de la Mosaïque Antique 13(1990-1991), 444-463; W. A. Daszewski, "Figural mosaics from Paphos. Subjects, Style and Signi Cance," in Mosaic Floors in Cyprus, Biblioteca di "Felix Ravenna" 3, ed. R. Farioli Campanati (Ravenna, 1988), 13-77; W. A. Daszewski, "Dionysos der Erlöser. Griechische Mythen im spä tantiken Cypern," in Trierer Beiträge zur Altertumskunde, Bd. 2, ed. G. Grimm (Mainz am Rhein, 1985).

4. H. Meyza, Nea Paphos: Pottery Finds from the House of Aion (Northern Sector), in Polish Archaeology in the Mediterranean XVIII, Reports 2006, ed. M. Gawlikowski, W. A. 
and other artefacts $^{6}$ that have helped to date the various phases of the development of this area. However, architectural studies ${ }^{7}$ on these buildings have not been completely published. It is still unknown how many building phases took place in this area, and there is no complete chronology of these buildings. Unclear also is the size of the House of Aion and the North-Eastern House and the plan of these buildings. Analysis of possible variants of the communication system in the buildings, lighting sources, water supply and drainage system have not been conducted to date, nor an analysis of the modifications of constructions of these buildings with the use of decorated architectural elements. There is no agreement on when the buildings were last occupied or what happened after the residents had left. The main function of the House of Aion is also unknown.

\section{Methodology}

My research was conducted partly in Poland, in the archives of the Centre of Mediterranean Archaeology of Warsaw University and the Institute of Mediterranean and Oriental Culture of the Polish Academy of Sciences, and partly in Paphos, at the archaeological site during the working seasons of the Polish Archaeological Mission.

I analyzed the documentation conducted during 1982 - 2008. A synthesis of data regarding the stratigraphic layers, the walls, the artifacts and the decorations was performed. Subsequently, during the work on the House of Aion and the North-Eastern House, the inventory of the walls, floors and thresholds was made. New photographic documentation was prepared with Agisoft PhotoScan, which will provide in the future a three-dimensional visualization of the solid objects. Orthophotomaps of the walls were created and the drawings of the walls with the marked phases were prepared in the AutoCad. In 3D Studio Max, 3D visualizations will be generated. The aim of these methods is to study possible variants of the communication system in the buildings, sources of light, several phases of construction and analysis of

Daszewski, I. Zych (Warsaw, 2008), 518-523; E. Papuci Władyka, Nea Pafos. Studia nad ceramika hellenistyczna z polskich wykopalisk (1965-1991) [Nea Paphos. Studies on Hellenistic pottery from Polish excavations (1965-1991)] (Kraków, 1995).

5. B. Lichocka, H. Meyza, Seismic events and the evidence of coins and pottery. The case of destruction of the House of Aion in Paphos, Etudes et Travaux Varsovie XIX(2001), 145-208.

6. H. Meyza and I. Zych (eds.), Nea Paphos: Sacred metropolis of Cypriot Cities, Warszawa [in press]; A. Brzozowska-Jawornicka, Reconstruction of a Façade of the House of Aion, Nea Paphos, Cyprus, Studies in Ancient Art And Civilization 20, Kraków, 2016, 151172; T. Mikocki, "Essai de reconstruction du mur Ouest de la salle I dans la 'Maison d'Aion' à Nea Paphos" ["Essay on reconstruction of the West Wall of Room I in the "House of Aion" in Nea Paphos"], Études et Travaux XVI(1992), 135-150; S. Medeksza, Reconstruction works in the House of Aion in Nea Paphos, Report of the Department of Antiquities Cyprus (Nicosia: 1987), $227-230$.

7. Part of the field documentation and many observations on the architecture of the late Roman insula I owe to Ms. Rądkowska, current employee of the Polish Centre of Mediterranean Archaeology, University of Warsaw. 
decorative architectural elements. This will also link building structures with iconographic program and help to determine the function of the House of Aion. In order to obtain a complete picture of the history and the functions of the House of Aion and the North-Eastern House it is necessary to make a comparative analysis.

\section{Findings/Results}

The House of Aion and the North-Eastern House are located on top of earlier buildings ${ }^{8}$. Surveys show that the oldest structures in this part of town date to the late Classical period ${ }^{9}$. In the Hellenistic period new structures in the insula 9B appeared ${ }^{10}$. During the Roman times the western part of this insula was replaced by structures belonging to the Villa of Theseus ${ }^{11}$. During the late Roman period, at the eastern facade of the Villa of Theseus, the North-South street was built. The construction of this street determined the creation of the House of Aion in the 4th century $\mathrm{AD}^{12}$. The North-Eastern House was built roughly at the same time or not long after. Traces of subsequent activity were also found in the House of Aion and the North-Eastern House. It is difficult to determine the final habitation of this area, although the latest fragments of ceramics date to the 6 th and 7 th centuries AD. (See Figure 2)

8. W. A. Daszewski, "Nea Paphos 1992," in Polish Archaeology in the Mediterranean IV, Reports 1992, ed. M. Gawlikowski, W. A. Daszewski (Warsaw, 1993), 85; W. A. Daszewski, "Nea Paphos 1990 Report," in, Polish Archaeology in the Mediterranean II, Reports 19891990, ed. M. Gawlikowski, W. A. Daszewski (Warsaw, 1991), 80.

9. J. R. Green, "The Theatre of Paphos and Theatre of Alexandria some First Thoughts," in The Library of Alexandria, Centre of Learning in Ancient World, ed. R. Macleod (London 2010), 116.

10. During the Hellenistic period, in this part of the town an insula, called by modern scholars 9B existed; cf. H. Meyza, "Archaeology of architectural remains - a case of Paphos" ["Archeologia reliktów architektury - przypadek Pafos"], in Non solum villae . Księga jubileuszowa ofiarowana profesorowi Stanisławowi Medekszy, ed. J. Kościuk, 229 - 238 (Wrocław, 2010). In the Roman period, the hellenistic city grid was disturbed in this part of Nea Paphos by the construction of the Villa of Theseus. In the late Roman period hellenistic insula 9B was partly builded by the House of Aion and the North-Eastern House.

11. W. A. Daszewski, La Mosä̈ue de Thésée: Études sur les mosä̈ues avec repréentations du labyrinthe de Thé sée et du Minotaure [The Mosaic of Theseus: Studies on mosaics with representations of the labyrinth of Theseus and the Minotaur] (Varsovie, 1997); S. Medeksza, Willa Tezeusza w Nea Pafos. Rezydencja antyczna, 1992, 5-8, 36-37, 42-45, 64-65, 69.

12. B. Lichocka, H. Meyza, Seismic events and the evidence of coins and pottery. The case of destruction of the House of Aion in Paphos, 2001, 145-208; W. A. Daszewski, "Nea Paphos 1965-1995," in Cypr w badaniach polskich . Materiaty z Sesji Naukowej zorganizowanej przez Centrum Archeologii Śr ódziemnomorskiej UW im. prof. K. Michałowskiego, Warszawa, 24-25 luty 1995, ed. W. A. Daszewski, H. Meyza (Warsaw, 1998), 12-15; W. A. Daszewski, "Dionysos der Erlöser. Griechische Mythen im spätantiken Cypern," 1985. 


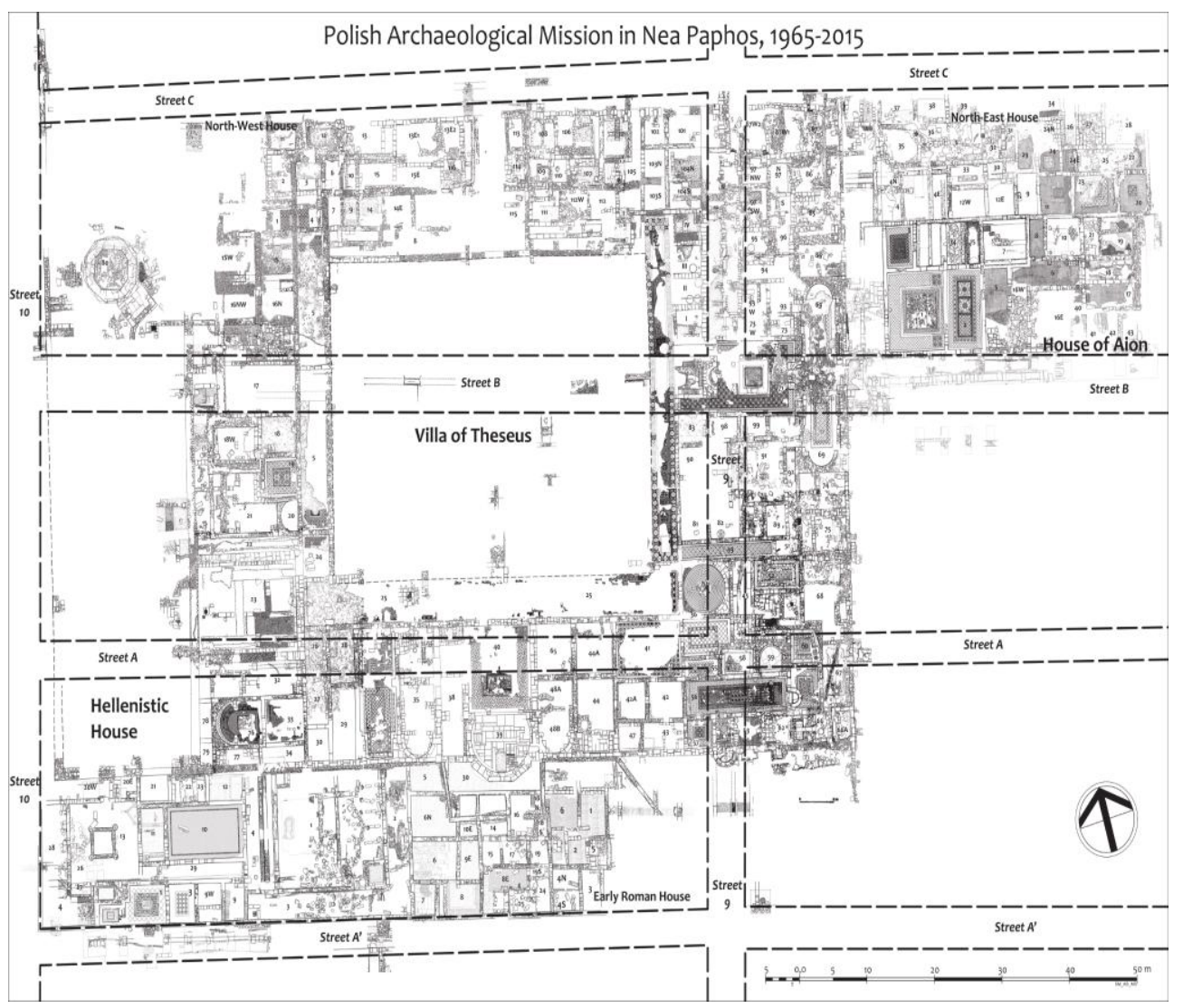

Figure 2. Street Grid in Nea Paphos

Source: Archive of the Polish Archaeological Mission in Nea Paphos.

The northern part of the late Roman insula is occupied by the so-called North-Eastern House (see Figure 3). The house was built on an east-west axis. The latest destruction of the North-Eastern House dates, on the basis of pottery analysis to the end of 5th century or the beginning of the 6th century. The latest coin is dated to the end of the 4th century (Valentian/ Valens)13. The building was destroyed by an earthquake in the late 4 th or early 5 th century 14 . There are however traces of later occupation of this area.

13. B. Lichocka and H. Meyza, Seismic events and the evidence of coins and pottery. The case of destruction of the House of Aion in Paphos, 176.

14. Ibid., 169-172. 


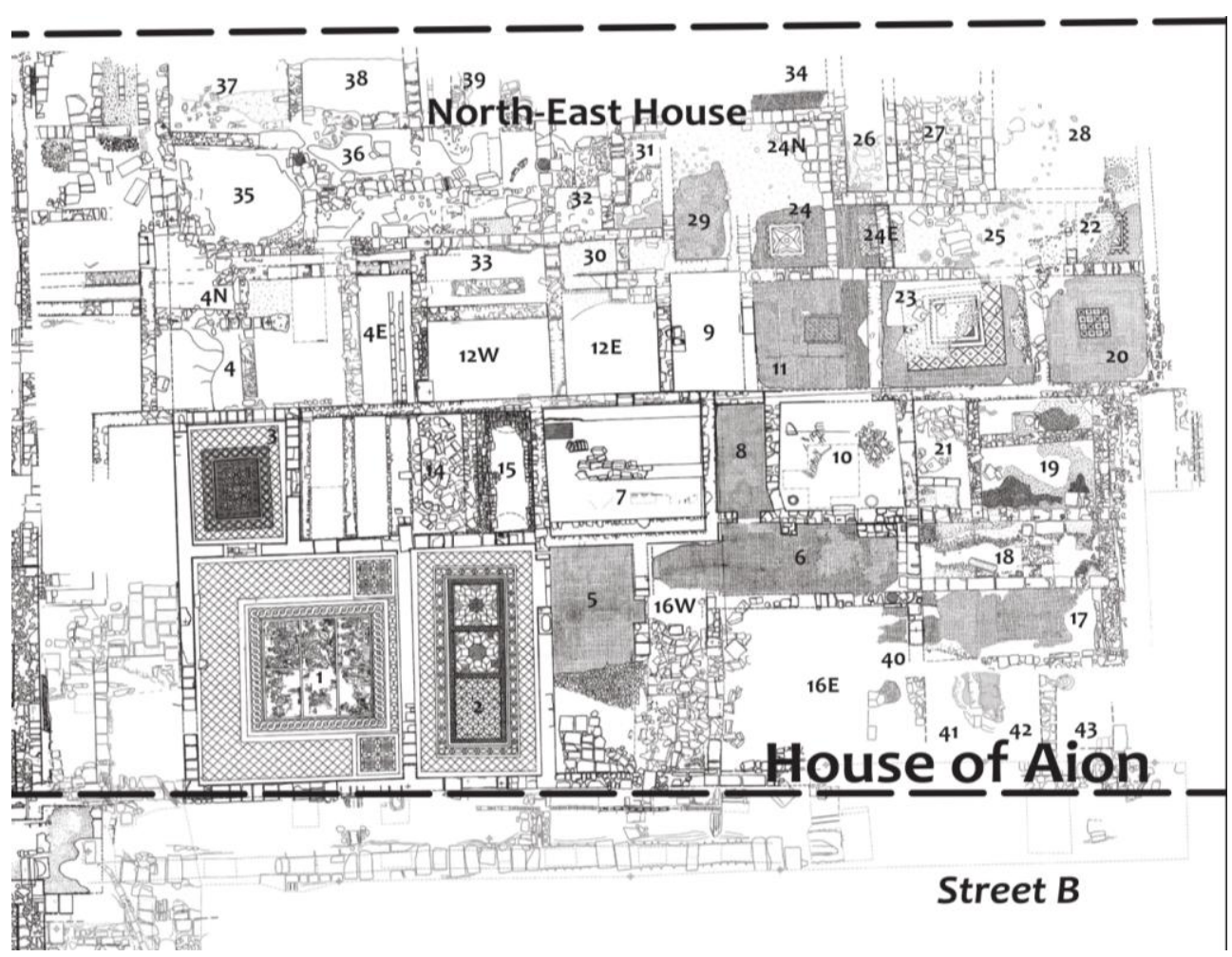

Figure 3. Plan of the North-Eastern House and House of Aion

Source: Archive of the Polish Archaeological Mission in Nea Paphos.

During the Constantine period mosaics in rooms 11, 20, 22, 23 and 24 were built. Late walls with shallow foundations corresponding to dust-covered floors also date to this period ${ }^{15}$. It is assumed that the eastern part of the NorthEast House, which has rooms with mosaics, was definitely the most important. The architectural patterns of the room $24 \mathrm{~N}$ and the floor, which was made of rectangular slabs, suggests that this area was a courtyard ${ }^{16}$. In room 27 the floor was made of stone slabs at presumably was an open space used for domestic purposes. Later, after the main phase of occupation of the North-Eastern House, this area was re-used by squatters who combined this facility into one complex with room $25^{17}$. Further to the east of room 27 , there were another rooms, but their damage makes their interpretation impossible ${ }^{18}$.

In the western part of the North-Eastern House several compartments were revealed but their functions are difficult to know. In the north-western part there were rooms with channels and cisterns. To the east of room 35 is a large

15. W. A. Daszewski, "Nea Paphos, 1998," in Polish Archaeology in the Mediterranean X, Reports 1998, ed. M. Gawlikowski, W. A. Daszewski, (Warsaw, 1999), 172 - 173.

16. W. A. Daszewski, H. Meyza and E. Papuci-Władyka, "Nea Paphos: Season 2005," in Polish Archaeology in the Mediterranean XVII, Reports 2005, ed. M. Gawlikowski, W. A. Daszewski (Warsaw, 2007), 398, 401.

17. Ibid., 401.

18. Ibid. 
courtyard, extending over an area of $9 \mathrm{~m}$ east to west ${ }^{19}$. Its northern wall is very ruined and it is not clear how it ran, just like the eastern end ${ }^{20}$.

The building located in the southern part of the late Roman insula is the so-called House of Aion, named because of the great mosaic in the main room with a representation of the Greek god of the time, Aion ${ }^{21}$. Other panels portray Leda and the Swan, Hermes and a young Dionysus, Cassiopeia, Apollo and Marsyas, and Dionysius with a thiasos. The building is considered to be a house, but its architectural plan, decoration and specific elements indicate that it could have served public functions.

Analysis of the architecture of the House of Aion indicates that there were few phases of this building, although there are traces of reconstructions ${ }^{22}$. The earliest walls date to the early Hellenistic period, and the pottery is from the classical period $^{23}$. This early building was destroyed during the construction of the Aion House. When the foundations of the House of Aion were discovered, they crossed the clay floor of the early Hellenistic house. Excavations have shown repairs to the Aion mosaic; the probable reconstructions of wall 001 ; the division of the entire room in two smaller rooms, in the eastern part of the insula (rooms 18-19) and the change of room $10^{24}$.

It seems that in the initial phase rooms 1, 2 and 3 were constructed. In room 1, over the mosaic, late Roman material from the 4th and 5th century and Byzantine material were located ${ }^{25}$. In the lime mortar, under the mosaic in room 1, a coin of the emperor Licinius was found. Mosaics in the vestibule, room 2 , and in room 3 appear to have been made at the same time ${ }^{26}$. It seems that during the next phase the western wall of room 1 was partially destroyed. During this period room 10 and room 19 functioned in its original form. Later, the reconstruction of the western wall of room 1 and the repairs of the mosaic with Aion occurred. During this period rooms 6 and 18 were in use, while room 10 and 19 functioned in a new form. During the next phase the building was

19. W. A. Daszewski, H. Meyza et al., "Nea Paphos: Season 2007," in Polish Archaeology in the Mediterranean XIX, Reports 2007, ed. M. Gawlikowski, W. A. Daszewski (Warsaw, 2010), 506.

20. W. A. Daszewski, H. Meyza, and E. Papuci-Władyka, "Nea Paphos: Season 2006," in Polish Archaeology in the Mediterranean XVIII, Reports 2006, edited by M. Gawlikowski, W. A. Daszewski (Warsaw, 2008), 509.

21. Cf. M. T. Olszewski, The iconographic programme of the Cyprus mosaic from the House of Aion has been reinterpreted as an anti-Christian polemic, 2013; M. T. Olszewski, "L'allégorie, les mystères dionysiaques et la mosaïque de la Maison d'Aiôn de Nea Paphos à Chypre," 1990-1991); W. A. Daszewski, Dionysos der Erlöser: griechische Mythen in spätantiken Cypern.

22. B. Lichocka and H. Meyza, Seismic events and the evidence of coins and pottery. The case of destruction of the House of Aion in Paphos, 150-154.

23. J. Młynarczyk, Trouvailles de cèramique ancienne [Ancient ceramics finds], in W. A. Daszewski, Mission Polonaise, Nea Paphos 1976-1983, Report of the Department of Antiquities, Cyprus (Nicosia, 1984), 309-311.

24. B. Lichocka and H. Meyza, Seismic events and the evidence of coins and pottery. The case of destruction of the House of Aion in Paphos, 150-154.

25. Ibid., 155.

26. Ibid., 153-154. 
finally destroyed. Its use was limited to a street south of the insula and to the use of limestone furnace in the ruins of House of Aion ${ }^{27}$.

In the House of Aion the main area is occupied by room 1 and room 2, both with mosaics. The walls of these rooms have mostly collapsed, with the best-preserved point the wall $70 \mathrm{~cm}$ above the mosaic. In room 1, the Aion mosaic is laid in typical form, which suggests that this room could be a triclinium. Fragments of glass vessels were found here, confirming that feasts took place in this compartment. Room 2 with a geometric mosaic is interpreted as a vestibule ${ }^{28}$. In the triclinium the niche in the western wall was reconstructed. The triclinium-vestibule unit in the House of Aion is located next to the one of the main streets of the city, called $\mathrm{B}^{29}$, which runs from the west to east, and leads from the residential Maloutena district to the Paphos harbour. This triclinium was not typical. It is located near the street. Normally in Cyprus, a triclinium was located in the back of the rooms. Here the triclinium is preceded by a large vestibule, which was accessible directly from the street, and performed partly a public function. It is assumed that the main entrance led from the street B to the vestibule. This part of the House of Aion was adorned by a monumental facade over the main gateway ${ }^{30}$ (see Figure 4 ).

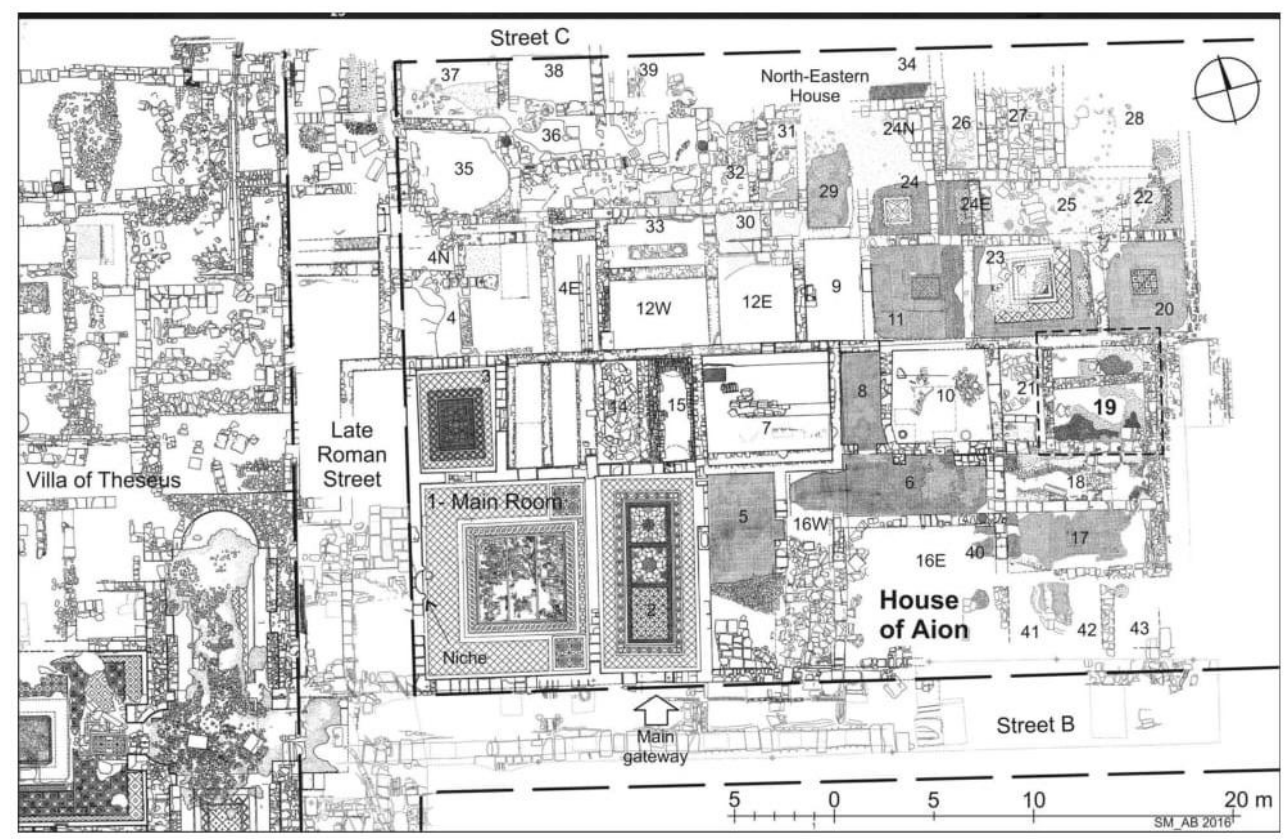

Figure 4. Plan of the House of Aion and North-Eastern House

Source: Archive of the Polish Archaeological Mission in Nea Paphos. Processing by S . Medeksza, M. Słowińska and A. Brzozowska-Jawornicka.

27. Ibid., 150.

28. Ibid., 155.

29. Cf. H. Meyza, Archaeology of architectural remains - a case of Paphos.

30. A. Brzozowska-Jawornicka, Reconstruction of a Façade of the House of Aion, Nea Paphos, 160-164. 
To the north of room 1 is room 3 with a geometric mosaic. The mosaic is located $40 \mathrm{~cm}$ lower than the mosaic in room 1 . Walls in room 3 have survived better than those of room 1 and room 2 , up to $90 \mathrm{~cm}$ above the mosaic ${ }^{31}$. There is a threshold between room 1 and room 3 . Room number 3 could have served representative purposes in the House of Aion.

To the east of room 3 are several constructions, rooms 13, 14, 15. Under the floor of the rooms 13 and 14, which are assumed to be a corridor, there is an empty space. Apart from the nails, no traces of the floor was found. The floor was probably wooden, made of wooden boards supported by transverse walls. In the eastern part of this corridor the boards were lying on the vault of a tank (number 15) available from the room 7 . Above the preserved cistern vault was the threshold to the vestibule. At the threshold, in this room, a goat skeleton was found ${ }^{32}$. Perhaps this area was used for rituals.

Another interesting room is located at the north-east corner of the vestibule-triclinium unit ${ }^{33}$. In room 7 benches, which served to reinforce the wooden floor, were found. There was also a doorway to cistern number 15 . Remains of painted plaster from the walls and ceilings were discovered there, with figural, geometric and vegetal motives. The figural panel was of extraordinary quality and included an image of a man with a kitharodos, perhaps Apollo. This motif was popular in wealthy houses, serving decorative purposes in libraries. Analogies may be seen in Ephesus. We do not know when the paintings were done in this room but they appear to be contemporary with the mosaics in the triclinium ${ }^{34}$. Numerous coins dated from 351-355 AD were found here and the oldest ceramics are dated to the 5th century ${ }^{35}$. The erection of the House of Aion must be connected with construction of this room.

In room 10, further east, two phases of use were detected. Originally room 10 had an official function. Fragments of paintings imitating marble and porphyry, with floral and geometric patterns and garlands of red flowers, fruit and green leaves were found ${ }^{36}$. In the second phase, four tanks were placed in the floor of the room. All elements indicate that in the second phase this room was used to store and to produce wine or olive oil. It seems that it was an open space. The final destruction of this room dates probably to the 5th century, likely by an earthquake ${ }^{37}$.

31. B. Lichocka and H. Meyza, Seismic events and the evidence of coins and pottery. The case of destruction of the House of Aion in Paphos, 157.

32. Ibid.

33. W. A. Daszewski, Nea Paphos 1990. Report, 80.

34. B. Lichocka and H. Meyza, Seismic events and the evidence of coins and pottery. The case of destruction of the House of Aion in Paphos, 154.

35. Ibid., 160, 162.

36. W. A. Daszewski, "Nea Paphos 1991," in Polish Archaeology in the Mediterranean III, Reports 1991, ed. M. Gawlikowski, W. A. Daszewski (Warsaw, 1992), 66; W. A. Daszewski, Nea Paphos 1992, 85.

37. W. A. Daszewski, "Nea Paphos 1998," 1999, 170-171. 
Room number 6 is considered a portico ${ }^{38}$. Room number $16 \mathrm{E}$ functioned as a courtyard. It seems that originally a single compartment existed there. Later it was divided in two by a large wall, on a west-east axis, with limestone blocks. This wall seem to be contemporary with the mosaic in room 6 . The precise date of the mosaics from rooms 5,6 and 8 is not clear but they are contemporary ${ }^{39}$. The entire area of compartment number 16 was plundered in the 5 th to 7 th centuries and later ${ }^{40}$.

It seems clear that originally the House of Aion extended further east and south, and that rooms in that part of the house were of an domestic nature.

To the east of room 10 were another compartments, 17-19 and 21. This part belongs to the last phase of the building, just before the destruction of the House of Aion. Their final state is the result of intensive redevelopment of the earlier phase. Pottery and coins found on and immediately below the last floor from room 18 and in the trench in the northern part of the room 19 suggests that these rooms were erected and the floors constructed during the late Constantinian period or soon after ${ }^{41}$. In room 17 a simple mosaic of large gray tesserae, with some black, white and brown was found. The same floor type was found in room 6 and room 8 . Room 18 was probably a corridor, which led to the entrance in room 6 on the west and to the entrance in room 19 to the north $^{42}$. Room 19 was the largest of all in this part of the House of Aion, and was lined with mortar stones. In room 19 a floor of the pebbles went south just below the northern wall of room 18, which is proof that this part of the building was previously organized in a different way. Originally there was a large, single structure. In the fill of room 19, among others, architectural elements were found. Thirteen fragments forming an arch, a lintel, an engaged column, an impost and two consoles were recognized. Dr. Aleksandra BrzozowskaJawornicka, an architect of the Polish Archaeological Mission in Nea Paphos, reconstructed these fragments as a part of the main gate of the House of Aion ${ }^{43}$. In room 17 the traces of the earlier, limestone floor were found, about $23 \mathrm{~cm}$ below the mosaic. During excavations in room 21 material from the 4th and 5th centuries was found ${ }^{44}$.

Research at the eastern and south-eastern part of the House of Aion are extremely important because they show that the house plan did not correspond to

38. B. Lichocka and H. Meyza, Seismic events and the evidence of coins and pottery. The case of destruction of the House of Aion in Paphos, 168.

39. W. A. Daszewski, Nea Paphos Excavations, 1988, 169.

40. Ibid.

41. B. Lichocka and H. Meyza, Seismic events and the evidence of coins and pottery. The case of destruction of the House of Aion in Paphos, 168, 201- 202; W. A. Daszewski, "Nea Paphos: Excavations 1997," in Polish Archaeology in the Mediterranean IX, Reports 1997, ed. M. Gawlikowski, W. A. Daszewski (Warsaw, 1998), 127-129; S. Hadjisavvas, "Chronique des fouilles et découvertes archéologiques à Chypre en 1997" ["Chronicle of excavations and archaeological discoveries in Cyprus in 1997"], Bulletin de Correspondance Hellénique 122, no. 2(1998), 691-692; W. A. Daszewski, Nea Paphos Excavations, 1998, 172-173.

42. W. A. Daszewski, Nea Paphos: Excavations 1997, 127-128.

43. Cf. A. Brzozowska-Jawornicka, Reconstruction of a Façade of the House of Aion, Nea Paphos, Cyprus, 151-172.

44. W. A. Daszewski, Nea Paphos Excavations, 1998, 171-172. 
the typical layout and plan of a house known from other examples from Nea Paphos $^{45}$. The divisions in this insula run along the urban area, rather than across it.

The area of the complex with the Aion mosaic still awaits excavations. The expansion of the excavation to the east of the room 19 has allowed the discovery of a massive wall, on a north-south axis, which could have served as the outer wall of this building ${ }^{46}$.

In the south-eastern part of the House of Aion rooms 40-43 were found. Room 40 could be a portico of the courtyard, dated to the 5th century. Two irregular columns-plinths were found in this room, as was a fragment of floor made of amphora and fragments of pottery mixed with mortar, evidently instead of ruined mosaic floor. The remains of this part are very damaged and fragments of the pure white mosaics in rooms 41-42 were found shifted along with part of the wall between the two rooms. The best preserved room is the one located to the east, numbered 43 , where traces of economic activity have been found: column drums were reused as a mortar ${ }^{47}$.

The House of Aion was separated from the North-Eastern House by a well-preserved wall in which a hole was discovered, perhaps a locked window or storage compartment. The North-Eastern House and the House of Aion were erected on a different levels; significant differences (about $40-50 \mathrm{~cm}$ ) in the floor levels of the latest floors of both buildings are observed. There is no evidence of a transition between the House of Aion and the North-Eastern House, but we cannot exclude that the House of Aion and the North EasternHouse were not, at least for a some time, a single residential complex.

It is assumed that the North-Eastern House served as a residential complex while some of the features of the rooms and iconography in the House of Aion indicate that this residence could have performed public functions. Perhaps residential rooms were located in the southeastern part but it is difficult to verify because this part of the House of Aion is very damaged. It is important to note that while the entire quarter of the city in late Roman period was abandoned, the House of Aion and the North-Eastern House functioned at least until the 6th century. This insula, for some reason, was distinguished from others. There are unusual features, not seen in other buildings from the area of Nea Paphos, such as the divisions in the insula running along the area, rather than across it, as in other insulas. In the House of Aion a complex of rooms decorated with mosaics (including a monumental mosaic with the representation of Aion), which were accessible from the street, a room with benches and wall paintings of high quality, and a complex of rooms with probably a wooden floor, which does not occur often in the architecture of this region, are worth mentioning. This is interesting in the context of the location of the House of Aion in the representative part of the city and in the immediate vicinity of the

45. W. A. Daszewski, Nea Paphos: Excavations 1997, 129.

46. H. Meyza, "Nea Paphos: Season 2008," in Polish Archaeology in the Mediterranean XX, Reports 2008, edited by I. Zych (Warsaw, 2011), 286.

47. H. Meyza, W. A. Daszewski et al. "Nea Paphos: Season 2009," in: Polish Archaeology in the Mediterranean XXI, Reports 2009, ed. I. Zych (Warsaw, 2012), 411. 
Villa of Theseus, the largest residential building in Cyprus, where 100 rooms were found. It is assumed that this building served some official function ${ }^{48}$. Of particular importance is the fact that at the time when the House of Aion and the North-Eastern House still functioned, the quarter in which the late Roman insula was located had already been abandoned.

Polish archaeologist discovered at Nea Paphos also the Villa of Theseus ${ }^{49}$. It is dated to the Roman period and functioned also during the late Roman period; a slow degradation of this residential complex started most likely in the 2nd half of the 5th century AD. In the 6th century AD the building was inhabited by squatters ${ }^{50}$. It is the largest residential building discovered to date in Cyprus. The form of this residence was derived from the Greek pastas house-type ${ }^{51}$. The Villa of Theseus was maintained in the Hellenistic tradition ${ }^{52}$. The plan of this building has certain structures: courtyards and porticoes, large entrance rooms, rooms with apses, baths and rich decorations. The southern wing of this residence dominates over the rest of the building and was the most representative part of this building. In the western zone of the house the private residence of the owner was situated, and in the north and east storage rooms were located $^{53}$. Villa of Theseus is a good example of how private peristyle house was designed to take over some functions relating to public life.

Villa of Theseus is the most impressive building discovered, to date, in Cyprus, the building is interpreted as a palatium. There are no direct analogies between the Villa of Theseus and the late Roman insula.

Late Roman houses were excavated at Kourion ${ }^{54}$ on Cyprus, but their architecture was functional, without peristyle courtyards, mosaics, paintings and apses. This indicates that the elite did not live here. It is not possible to compare these structures to the late Roman insula in Nea Paphos.

Some late Roman structures, probably also residential, were found at Kalavasos-Kopetra, but excavations were too limited and so we cannot compare the architecture from Nea Paphos to these structures ${ }^{55}$.

Based on the information described above there is no direct analogy by which to compare the late Roman architecture of the North-Eastern House and the House of Aiona and to help interpret the function of the House of Aion. Structures discovered so far in Cyprus either do not coincide with the

48. Ibid.

49. W. A. Daszewski, La Mosaïque de Thésée Études sur les mosaïques avec représentations du labyrinthe de Thésée et du Minotaure ; S. Medeksza, Willa Tezeusza w Nea Pafos. Rezydencja antyczna.

50. S. Medeksza, Willa Tezeusza w Nea Pafos. Rezydencja antyczna, 5-8; 42-45.

51. Ibid., 64.

52. Ibid., 69.

53. Ibid., 36-37.

54. Cf. B. Costello, Architecture and material culture from the Earthquake House at Kourion, Cyprus a late Roman non-elite house destroyed in the 4th century AD, BAR International Series 2635, 2014.

55. M. L. Rautman, "Cyprus at the end of Antiquity. Investigations at Kalavasos-Kopetra," Muse. Annual of the Museum of Art and Archaeology, University of Missouri (Columbia, 21, 1987), 45-54. 
chronology of the late Roman insula or have no analogy to the characteristics of the insula.

Nea Paphos in Cyprus is located in the eastern part of the Mediterranean Basin. This well-preserved ancient city was founded in the Hellenistic period, during the reign of the Ptolemies, with the monuments from Greek, Roman and Byzantine times ${ }^{56}$. Nea Paphos was Greek speaking when brought under Ptolemaic rule ${ }^{57}$. The city minted its own $\operatorname{coin}^{58}$, and at the end of the $3 \mathrm{rd}$ century BC it was probably the seat of the Ptolemy governor ${ }^{59}$. From the second half of the 1 st century BC Cyprus became a senatorial province. It is assumed that Nea Paphos was the capital of Cyprus during the Hellenistic period and of the Roman province of Cyprus ${ }^{60}$. In the 2 nd and 3rd centuries $\mathrm{AD}$, the city developed as never before. After an earthquake in 332, Nea Paphos lost the status of the capital of Cyprus, but art and culture still flourished there. From the 4th century Nea Paphos was the capital of the bishopric, and in the 7th century the life of the Christian community of the city focused around the churches, although later the city fell into ruin ${ }^{61}$. Cyprus was one of the Mediterranean trade centers. It is assumed that one of the trade routes ran through Cyprus to Crete, then to the Libyan coast, to the Nile, and to the coast of Syria ${ }^{62}$. In ancient Cyprus lived Greek citizens, Persians, people from Cyrenaica and Egypt, and then also Roman citizens ${ }^{63}$. The island was an

56. W. A. Daszewski, "Nea Paphos 1993," in Polish Archaeology Mediterranean V, Reports 1993, ed. M. Gawlikowski, W. A. Daszewski. (Warsaw, 1994), 101, 105, 108.

57. G. R. H. Wright, "Roman Cyprus and Roman Cyrenaica. An Architectural Contrast within Historical Paralells," in Cypriot Connections. An Archaeological Chronicle, Peleus: Studien zur Archäologie und Geschichte Griechenlands und Zyperns, ed. G. R. H. Wright, 173. Band 53

58. W. A. Daszewski, "Les fouilles polonaises à Nea Paphos 1972-1975. Rapport préliminaire" ["Polish excavations at Nea Paphos 1972-1975. Preliminary report"], Report of the Department of Antiquities, Cyprus (Nicosia, 1976), 217; W. A. Daszewski, "Polish excavations at Kato (Nea) Paphos in 1970 and 1971," Report of the Department of Antiquities, Cyprus (Nicosia, 1972); K. Nicolaou, "Discovery of a Ptolemaic mint at Nea Paphos," Proceedings of a Ist International Congress of Cypriot Studies (Nicosia, 1972).

59. W. A. Daszewski, "The beginnings of Nea Paphos," Proceedings of the International Congress of Classical Archaeology, September 1983 (Athens, 1988), 49-53; W. A. Daszewski, "A preliminary report on excavations of the Polish Archaeological Mission at Kato (Nea) Paphos in 1966 and 1967," Report of the Department of Antiquities, Cyprus (Nicosia, 1968), 33.

60. About the doubts whether Nea Paphos was the capital of Cyprus cf. R. Haensch, "Capita provinciarum: Statthaltersitze und Provinzialverwaltung in der römischen Kaiserzeit" ["Capita provinciarum: governor seats and provincial administration in the Roman Empire"], Kölner Forschungen 7 (Mainz, 1997). 1984).

61. Cf. F. G. Maier and V. Karageorghis, Paphos. History and Archaeology (Nicosia,

62. Cf. C. Gillis, "Trade in the Late Bronze Age," in CTrade and Production in Premonetary Greece: Aspects of Trade [SIMA Pocketbook 134], ed. C. Gillis, B. Risberg, Sjöberg (Jonsered, 1995), 61-86.

63. Cf. I. Nicolaou, "Cypriots in the East and West. Foreigners in Cyprus. Archaic to Roman period," in Cyprus between the Orient and the Occident. Acts of the International Archaeological Symposium, Nicosia 8 - 14 September 1985, ed. V. Karageorghis (Nicosia, 1986). 
ancient crossroads of cultures of the Eastern Mediterranean ${ }^{64}$. Cyprus, due to its geographic location, has never ceased to be a meeting place and a bridge between East and West ${ }^{65}$.

Based on these facts, it is clear that in the architecture of the late Roman insula of Nea Paphos, influences from other surrounding regions can be observed. Interpretation of the architecture of the late Roman insula should be based on analogies to different parts of Mediterranean World.

It is safe to conclude that information on residential architecture in Cyprus indicate that residential building in Cyprus during the Hellenistic and Roman periods refers more to Greek than to Roman patterns, but the traces of Romanization in private and public life are visible ${ }^{66}$. The residential architecture have the same characteristics as other Roman buildings from former Greek World. The buildings were centered around the peristyle, and the secondary role of atrium is seen. In some residences the oecus functioned as a representative room $^{67}$. In the late Roman period rooms with apses connected to a peristyle or triclinium appeared. In the late Roman and Byzantine periods, rooms of houses were divided and reduced in size, remodeled by squatters. Small workshops or other craft activities on a local scale took place there. In the architecture of Nea Paphos an analogy to Alexandria appears, mainly architectural elements, for example, in the form of Corinthian capitals. Particularly popular in Cyprus was the heterodox Corinthian capital associated with Alexandria. Nabataean capitals were also used in Cyprus and are found at Nea Paphos. During research on some of residential architecture in Nea Paphos a limited amount of tiles was discovered. Perhaps the buildings were covered with flat roofs or terraces. This is typical for the Eastern-mediterranean tradition.

Some of these characteristics are seen in the case of the North-Eastern House, where there are open courtyards, but no trace of atrium. In the NorthEastern House a clear division between representative and domestic parts are observed. The House of Aion also is a type of building with courtyard with porticos, triclinium and without an atrium. In the southern facade of the House of Aion, with a main gateway, elements typical for the ancient baroque style can be observed ${ }^{68}$.

64. W. M. Murray, "Ancient Sailing Winds. The case for Cyprus," in Proceedings of the International Symposium Cyprus and the Sea, ed. V. Karageorghis, D. Michaelides (Nicosia, 1995), 38.

65. I. Nicolaou, Cypriots in the East and West. Foreigners in Cyprus. Archaic to Roman period, 423

66. Ch. Kondoleon, Domestic and Divine Roman mosaics in the House of Dionysos (Ithaca and London, 1995), 6.

67. J. Mikocka, "Residential architecture in Ptolemais (Libya) and Nea Paphos (Cyprus): preliminary results of a comparative analysis)," in In the heart of the ancient city. Five years of Krakow Archaeologists' research at the Paphos Agora ion Cyprus (2011-2015) International Symposium organized by the Department of Classical Archaeology at the Institute of Archaeology, Jagiellonian University, 21-22 January 2016), edited by E. Papuci-Władyka, A. Dobosz (Kraków, 2016), 80 - 82.

68. A. Brzozowska-Jawornicka, Reconstruction of a Façade of the House of Aion, Nea Paphos, 164. 


\section{Conclusions}

Professor Daszewski, the longtime head of Polish Archaeological Mission at Nea Paphos, believes that the House of Aion was the seat of the pagan religious-philosophical association at a time, when Christianity was spreading on the island ${ }^{69}$. But this hypothesis is still to be proved and research on the functions of the House of Aion is still in progress. In the residential architecture of Cyprus influences of Greek, Roman, Alexandrian and Levantine traditions continued. So the analogies to the architecture of the late Roman insula could be found among residences in the regions indicated above. Studies on the architecture of the late Roman insula and functions of the House of Aion should be continued.

\section{Bibliography}

Brzozowska-Jawornicka, A. Reconstruction of a Façade of the House of Aion, Nea Paphos, Cyprus. Studies in Ancient Art and Civilization 20, 151-172. Kraków, 2016.

Costello, B. 2014. Architecture and material culture from the Earthquake House at Kourion, Cyprus a late Roman non-elite house destroyed in the 4th century AD, BAR International Series 2635.

Daszewski, W. A. "A preliminary report on excavations of the Polish Archaeological Mission at Kato (Nea) Paphos in 1966 and 1967." Report of the Department of Antiquities, Cyprus, 33-61.Nicosia, 1968.

Daszewski, W. A. "Polish excavations at Kato (Nea) Paphos in 1970 and 1971." Report of the Department of Antiquities, Cyprus, 204-236. Nicosia, 1972.

Daszewski, W. A. "Les fouilles polonaises à Nea Paphos 1972-1975. Rapport préliminaire" ["Polish excavations at Nea Paphos 1972-1975. Preliminary report"], Report of the Department of Antiquities, Cyprus, 185-225. Nicosia, 1976.

Daszewski, W. A. "Dionysos der Erlöser. Griechische Mythen im spätantiken Cypern" ["Dionysus the Redeemer. Greek myths in late antique Cyprus"]. In Trierer Beiträge zur Altertumskunde, edited by G. Grimm, Bd. 2. Mainz am Rhein, 1985.

Daszewski, W. A. "Figural Mosaics from Paphos, Cyprus: Subjects, Style and Significance." In Floor Mosaics in Cyprus, edited by W. A. Daszewski, D. Michaēlidēs, 13-77. Biblioteca di "Felix Ravenna" 3. Ravenna, 1988.

Daszewski, W. A. "The beginnings of Nea Paphos." Proceedings of the International Congress of Classical Archaeology, September 1983, 49-53.Athens, 1988.

Daszewski, W. A.. "Nea Paphos 1990 Report." In Polish Archaeology in the

Mediterranean II, Reports 1989-1990, edited by M. Gawlikowski, W. A. Daszewski, 78-84. Warsaw, 1991.

Daszewski, W. A. "Nea Paphos 1990 Report." In Polish Archaeology in the Mediterranean II, Reports 1989-1990, edited by M. Gawlikowski, W. A. Daszewski , 78-84. Warsaw, 1991.

Daszewski, W. A. "Nea Paphos 1991." In Polish Archaeology in the Mediterranean III, Reports 1991, edited by M. Gawlikowski, W. A. Daszewski, 59-67. Warsaw, 1992.

69. W. A. Daszewski, Dionysos der Erlöser: Griechische Mythen in Spätantiken Cypern. 
Daszewski, W. A. "Nea Paphos 1992." In Polish Archaeology in the Mediterranean IV, Reports 1992, edited by M. Gawlikowski, W. A. Daszewski, 83-93. Warsaw, 1993.

Daszewski, W. A. "Nea Paphos 1993." In Polish Archaeology in the Mediterranean V, Reports 1993, edited by M. Gawlikowski, W. A. Daszewski, 101-110. Warsaw, 1994.

Daszewski, W. A. La Mosaïque de Thésée: Études sur les mosaïques avec représentations du labyrinthe de Thésée et du Minotaure [The Mosaic of Theseus: Studies on mosaics with representations of the labyrinth of Theseus and the Minotaur]. Varsovie, 1997.

Daszewski, W. A. "Nea Paphos 1965-1995." In Cypr w badaniach polskich. Materiaty z Sesji Naukowej zorganizowanej przez Centrum Archeologii Śródziemnomorskiej UW im. prof. K. Michałowskiego, Warszawa, 24-25 luty 1995, edited by W. A. Daszewski, H. Meyza, 5-23. Warsaw, 1998

Daszewski, W. A. "Nea Paphos: Excavations 1997." In Polish Archaeology in the Mediterranean IX, Reports 1997, edited by M. Gawlikowski, W. A. Daszewski, 119-129. Warsaw, 1998.

Daszewski, W. A. Nea Paphos 1998. In Polish Archaeology in the Mediterranean X, Reports 1998, edited by M. Gawlikowski, W. A. Daszewski, 163-173. Warsaw, 1999.

Daszewski, W. A., Meyza, H. et al. "Nea Paphos: Season 2007." In Polish Archaeology in the Mediterranean XIX, Reports 2007, ediered by M. Gawlikowski, W. A. Daszewski, 503-514. Warsaw, 2010.

Daszewski, W. A., Meyza, H. and E. Papuci-Władyka. "Nea Paphos: Season 2005." In Polish Archaeology in the Mediterranean XVII, Reports 2005, edited by M. Gawlikowski, W. A. Daszewski, 393-407. Warsaw, 2007.

Daszewski, W. A., Meyza, H. and E. Papuci-Władyka. "Nea Paphos: Season 2006." In Polish Archaeology in the Mediterranean XVIII, Reports 2006, edited by M. Gawlikowski, W. A. Daszewski, 507-517. Warsaw, 2008.

Gillis, C. "Trade in the Late Bronze Age." In Trade and Production in Premonetary Greece: Aspects of Trade [SIMA Pocketbook 134], edited by C. Gillis, C. Risberg and B. Sjöberg, 61-81. Jonsered, 1995.

Green, J. R. "The Theatre of Paphos and Theatre of Alexandria some First Thoughts." In The Library of Alexandria, Centre of Learning in Ancient World, edited by R. Macleod, 115-126. London, 2010.

Hadjisavvas, S. "Chronique des fouilles et découvertes archéologiques à Chypre en 1997" ["Chronicle of excavations and archaeological discoveries in Cyprus in 1997"]. Bulletin de Correspondance Hellénique, 122 no. 2(1998), 689-692.

Haensch, R. "Capita provinciarum: Statthaltersitze und Provinzialverwaltung in der römischen Kaiserzeit" ["Capita provinciarum: governor seats and provincial administration in the Roman Empire"]. Kölner Forschungen 7. Mainz, 1997.

Kondoleon, Ch. Domestic and Divine. Roman mosaics in the House of Dionysos. Ithaca and London, 1995.

Lichocka, B. and H. Meyza. Seismic events and the evidence of coins and pottery. The case of destruction of the House of Aion in Paphos. Etudes et Travaux Varsovie XIX(2001), 145-208.

Maier, F. G., and V. Karageorghis. Paphos. History and Archaeology. Nicosia, 1984.

Medeksza, S. Reconstruction works in the House of Aion in Nea Paphos. Report of the Department of Antiquities Cyprus. Nicosia, 1987, 227 - 230. 
Medeksza, S. Willa Tezeusza w Nea Pafos. Rezydencja antyczna [Villa of Theseus in Nea Paphos. Antique residence]. Wrocław, 1992.

Meyza, H. Nea Paphos: Pottery Finds from the House of Aion (Northern Sector). In Polish Archaeology in the Mediterranean XVIII, Reports 2006, edited by M. Gawlikowski, W. A. Daszewski, I. Zych, 518-523. Warsaw, 2008.

Meyza, H. "Archaeology of architectural remains - a case of Paphos" ["Archeologia reliktów architektury - przypadek Pafos"]. In Non solum villae. Księga jubileuszowa ofiarowana profesorowi Stanistawowi Medekszy, edited by J. Kościuk, 229 - 238. Wrocław, 2010.

Meyza, H. "Nea Paphos: Season 2008." In Polish Archaeology in the Mediterranean XX, Reports 2008, edited by I. Zych, 283-294. Warsaw, 2011.

Meyza, H., Daszewski, W. A. et al. Nea Paphos: Season 2009. In Polish Archaeology in the Mediterranean XXI, Reports 2009, edited by I. Zych, 407-422. Warsaw, 2012.

Meyza, H. and I. Zych, Nea Paphos: Sacred metropolis of Cypriot Cities, Warszawa [in press]

Mikocka, J. "Residential architecture in Ptolemais (Libya) and Nea Paphos (Cyprus): preliminary results of a comparative analysis." In In the heart of the ancient city. Five years of Krakow Archaeologists' research at the Paphos Agora on Cyprus (2011-2015). International Symposium organized by the Department of Classical Archaeology at the Institute of Archaeology, Jagiellonian University, 21-22 January 2016, edited by E. Papuci Władyka and A. Dobosz, 80-82. Kraków, 2016.

Mikocki, T. "Essai de reconstruction du mur Ouest de la salle I dans la 'Maison d'Aion' à Nea Paphos" ["Essay on reconstruction of the West Wall of Room I in the "House of Aion" in Nea Paphos"]. Études et Travaux XVI(1992), 135-150.

Murray, W. M. "Ancient Sailing Winds. The case for Cyprus." In Proceedings of the International Symposium Cyprus and the Sea, edited by V. Karageorghis, D. Michaelides, 33-44. Nicosia, 1995.

Młynarczyk, J. Trouvailles de cèramique ancienne [Ancient ceramics finds]. In Mission Polonaise, Nea Paphos 1976-1983, W. A. Daszewski. Report of the Department of Antiquities, Cyprus, 309-311Nicosia: 1984.

Młynarczyk, J. 1990. Nea Paphos III. Nea Paphos in Hellenistic period, Varsovie.

Nicolaou, I. "Cypriots in the East and West. Foreigners in Cyprus. Archaic to Roman period." In Cyprus between the Orient and the Occident, edited by V. Karageorghis, Acts of the International Archaeological Symposium, Nicosia 8 14 September 1985, 423-438. Nicosia, 1986.

Nicolaou, K. "Discovery of a Ptolemaic mint at Nea Paphos." Proceedings of a Ist International Congress of Cypriot Studies, 121-124.Nicosia, 1972.

Olszewski, M. T. "L'allégorie, les mystères dionysiaques et la mosaïque de la Maison d'Aiôn de Nea Paphos à Chypre" ["The allegory, the Dionysian mysteries and the mosaic of the Aiôn House of Nea Paphos in Cyprus"]. Bulletin de l'Association Internationale pour l'Étude de la Mosaïque Antique 13(1990-1991), 444-463.

Olszewski, M. T. The iconographic programme of the Cyprus mosaic from the House of Aion reinterpreted as an anti-Christian polemic. In Et in Arcadia ego. Studia memoriae Professoris Thomae Mikocki dicata, edited by Vitoldo Dobrowolski, 207-239. Varsoviae, 2013.

Papuci Władyka, E. Nea Pafos. Studia nad ceramika hellenistyczna z polskich wykopalisk (1965-1991) [Nea Paphos. Studies on Hellenistic pottery from Polish excavations (1965-1991)]. Kraków, 1995.

Rautman, M. L. "Cyprus at the end of Antiquity." Investigations at KalavasosKopetra. Muse. Annual of the Museum of Art and Archaeology, University of Missouri, 45-54. Columbia 21, 1987. 
Wright, G. R. H. "Roman Cyprus and Roman Cyrenaica. An Architectural Contrast within Historical Paralells." In Cypriot Connections. An Archaeological Chronicle, Peleus: Studien zur Archäologie und Geschichte Griechenlands und Zyperns, edited by G. R. H. Wright, 157-162. Band 53. 